\title{
Affinity profiles of hexahydro-sila-difenidol analogues at muscarinic receptor subtypes
}

\author{
Günter Lambrecht *, Roland Feifel, Monika Wagner-Röder, Carsten Strohmann ${ }^{1}$, \\ Harald Zilch ${ }^{1}$, Reinhold Tacke ${ }^{1}$, Magali Waelbroeck ${ }^{2}$, Jean Christophe ${ }^{2}$, \\ Hendrikus Boddeke ${ }^{3}$ and Ernst Mutschler \\ Department of Pharmacology, University of Frankfurt, D-6000 Frankfurt/M, F.R.G., ' Institute of Inorganic Chemistry, \\ University of Karlsruhe, D-7500 Karlsruhe, F.R.G., '2 Department of Biochemistry and Nutrition, Medical School, \\ Free University of Brussels, B-1000 Brussels, Belgium, and ${ }^{3}$ Preclinical Research, Sandoz Lid., CH-4002 Basel, Switzerland
}

Received 20 April 1989, accepted 13 June 1989

In an attempt to assess the structural requirements of hexahydro-sila-difenidol for potency and selectivity, a series of analogues modified in the amino group and the phenyl ring were investigated for their affinity to muscarinic $M_{1}$ (rabbit vas deferens), $M_{2-}$ (guinea-pig atria) and $\mathrm{M}_{3^{-}}$(guinea-pig ileum) receptors. All compounds were competitive antagonists in the three tissues. Their affinities to the three muscarinic receptor subtypes differed by more than two orders of magnitude and the observed receptor selectivities were not associated with high affinity. The pyrrolidino and hexamethyleneimino analogues, compounds substituted in the phenyl ring with a methoxy group or a chlorine atom as well as p-fluoro-hexahydro-difenidol displayed the same affinity profile as the parent compound, hexahydro-sila-difenidol: $\mathbf{M}_{1} \approx \mathbf{M}_{3}>\mathbf{M}_{2}$. A different selectivity pattern was observed for p-fluoro-hexahydro-sila-difenidol: $\mathbf{M}_{3}>\mathbf{M}_{1}>$ $\mathbf{M}_{2}$. This compound exhibited its highest affinity for $\mathbf{M}_{3}$-receptors in guinea-pig ileum $\left(\mathrm{pA}_{2}=7.84\right.$ ), intermediate affinity for $\mathrm{M}_{1}$-receptors in rabbit vas deferens $\left(\mathrm{pA}_{2}=6.68\right)$ and lowest affinity for the $\mathrm{M}_{2}$-receptors in guinea-pig atria $\left(\mathrm{pA}_{2}=6.01\right)$. This receptor selectivity profile of $\mathrm{p}$-fluoro-hexahydro-sila-difenidol was confirmed in ganglia $\left(\mathrm{M}_{1}\right)$, atria $\left(M_{2}\right)$ and ileum $\left(M_{3}\right)$ of the rat. Furthermore, dose ratios obtained with either pirenzepine $\left(M_{1}\right)$ or hexahydrosila-difenidol $\left(\mathrm{M}_{2}\right.$ and $\left.\mathrm{M}_{3}\right)$ and the p-fluoro analogue used in combination suggested that the antagonism was additive, implying mutual competition with a single population of muscarinic receptor subtypes. These results indicate that p-fluoro-hexahydro-sila-difenidol represents a valuable tool for characterization of muscarinic receptor subtypes.

Muscarinic receptor subtypes; Muscarinic $\mathrm{M}_{3}$-selective antagonists; Hexahydro-sila-difenidol analogues; p-Fluoro-hexahydro-sila-difenidol; Pirenzepine; Methoctramine; Vas deferens (rabbit); Ganglia (rat); (Structure-activity relationships)

\section{Introduction}

Radioligand binding and functional data, have allowed the clear demonstration that there are at least three major subtypes of muscarinic recep-

\footnotetext{
* To whom all correspondence should be addressed: Department of Pharmacology, University of Frankfurt, TheodorStern-Kai 7, Gebäude 75A, D-6000 Frankfurt/M, F.R.G.
}

tors: $M_{1}$ (neuronal type), $\mathbf{M}_{2}$ (cardiac type; $\mathbf{M}_{2 \alpha}$, Mutschler et al., 1988) and $\mathbf{M}_{3}$ (smooth muscle/ glandular type; $\mathbf{M}_{2 \beta}$, Mutschler et al., 1988) (for recent reviews, see Birdsall and Hulme, 1983; Eglen and Whiting, 1986; Mitchelson, 1988; Mutschler et al., 1988). $M_{1}$-receptors are found in high density in neuronal tissues such as autonomic ganglia, cerebral cortex and hippocampus, whereas $\mathrm{M}_{2-}$ and $\mathrm{M}_{3}$-receptors are mainly present in lower brain areas and in peripheral effector organs such 
as heart $\left(M_{2}\right)$, smooth muscle $\left(M_{3}\right)$ and glands $\left(\mathrm{M}_{3}\right)$. This pharmacological subclassification of muscarinic receptors is based mainly on the different affinities of selective antagonists such as pirenzepine $\left(M_{1}>M_{2} \approx M_{3}\right)$ (Hammer et al., 1980; Hammer and Giachetti, 1982; Doods et al., 1987; Lambrecht et al., 1988c; Waelbroeck et al., $1986 ; 1988)$, methoctramine and AF-DX $116\left(\mathrm{M}_{2}\right.$ $>M_{1}>M_{3}$ ) (Melchiorre et al., 1987; Micheletti et al., 1987; Melchiorre, 1988; Waelbroeck et al., $1988)$, and hexahydro-sila-difenidol $\left(M_{1} \approx M_{3}>\right.$ $\mathrm{M}_{2}$ ) (Fuder et al., 1985; Giraldo et al., 1988; Lambrecht et al., 1988a; Waelbroeck et al., 1988).

More recently, differences in the amino acid sequences of muscarinic receptor subtypes have been demonstrated by cloning, sequencing and expression of complementary DNA encoding these receptors (Kerlavage et al., 1987; Peralta et al., 1987; Akiba et al., 1988; Brann et al., 1988). The antagonist binding properties of the individual cloned receptors $(\mathrm{m} 1, \mathrm{~m} 2$ and $\mathrm{m} 3)$ and their patterns of expression in various tissues correspond closely to those of the pharmacologically defined $\mathbf{M}_{1}-, \mathbf{M}_{2}-$ and $\mathbf{M}_{3}$-receptors, respectively (Peralta et al., 1987; Akiba et al., 1988; Buckley et al., 1989).

Hexahydro-sila-difenidol ( 1 , fig. 2$)$ was discovered in the course of structure-activity (selectivity) relationship studies of a series of difenidol and sila-difenidol analogues (fig. 1) (for recent reviews, see Tacke and Becker, 1987; Mutschler et al., 1988). Structurally, these molecules consist of a central carbinol (silanol) carbon (silicon) atom carrying an $\mathrm{OH}$ group, two ring systems and an aminoalkyl group $\left[\left(\mathrm{CH}_{2}\right)_{\mathrm{n}}-\mathrm{NR}_{2}\right]$ (figs. 1 and 2). It was found in preceding investigations that the potency and selectivity of the difenidol and sila-<smiles>[R]C(O)(CCCN1CCCCC1)c1ccccc1</smiles>

Fig. 1. General formula of antimuscarinic agents of the difenidol $(E l=C, R=$ phenyl, $n=3)$ and sila-difenidol $(E l=S i$, $\mathrm{R}=$ phenyl, $\mathrm{n}=3$ ) type. $\mathrm{El}=\mathrm{C}, \mathrm{Si} ; \mathrm{R}=$ aryl, cycloalkyl; $\mathrm{n}=$ $1-4$.

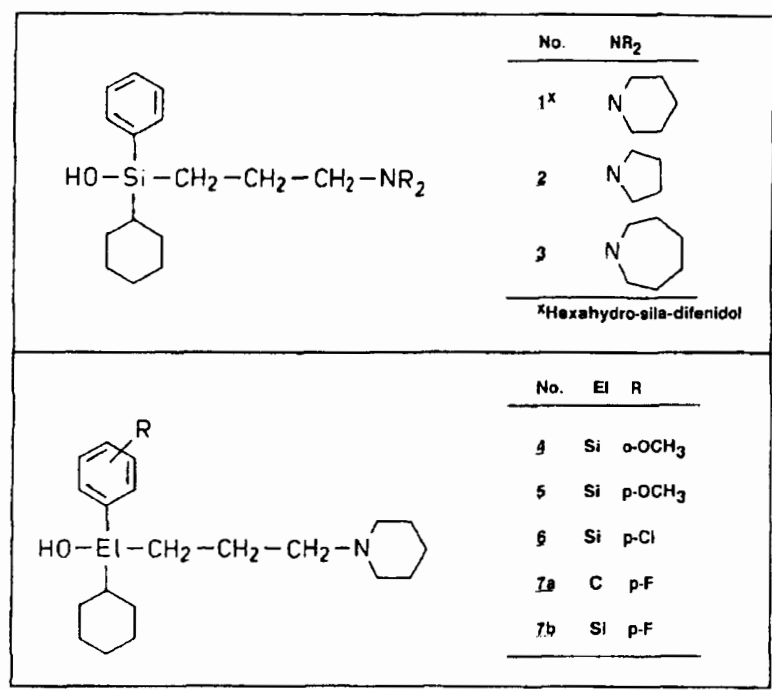

Fig. 2. Chemical structure of hexahydro-sila-difenidol (1 1 ) and its analogues $\underline{2}-\underline{6}, \underline{7 a}$ and $\underline{7 b}$.

difenidol analogues are controlled by the nature of the central atom $(\mathrm{El}=\mathrm{C}, \mathrm{Si})$ and the structure of the ring system ' $R$ ' bound to this atom, the absolute configuration at the central atom and the length of the alkylene chain (Tacke et al., 1986; 1987; 1989; Eltze et al., 1988; Lambrecht et al., $1988 \mathrm{~b} ; 1989)$. The main goal of the present study was to characterize the structural demands for potency and selectivity among hexahydro-sila-difenidol analogues modified in the cyclic amino group and in the phenyl ring system. Consequently, the antagonist affinities of compounds $\underline{2}-\underline{6}, 7 \mathrm{a}$ and $7 \mathrm{~b}$ (fig. 2) were determined and compared with those obtained for the parent compound hexahydro-sila-difenidol (1) and the reference drugs pirenzepine and methoctramine. The receptors studied were $\mathbf{M}_{1}$-receptors in rabbit vas deferens (Eltze, 1988; Eltze et al., 1988), cardiac $\mathrm{M}_{2}$-receptors in guinea-pig atria and smooth muscle $\mathrm{M}_{3}$-receptors in guinea-pig ileum. Furthermore, we report on in vitro experiments with hexahydro-sila-difenidol and its p-fluoro derivative $7 \mathrm{~b}$ in ganglionic $\left(\mathbf{M}_{1}\right)$, atrial $\left(\mathbf{M}_{2}\right)$ and ileal $\left(\mathrm{M}_{3}\right)$ preparations of the rat.

The agonist independence of the antagonism was investigated to verify the mechanism of action of p-fluoro-hexahydro-sila-difenidol (7b) (Lambrecht et al., 1988a). In addition, antagonist com- 
bination experiments were carried out and analyzed according to the dose-ratio method of Paton and Rang (1965). The results are discussed in terms of their implications for muscarinic receptor classification.

\section{Materials and methods}

\subsection{Rabbit isolated vas deferens}

Experiments on rabbit isolated vas deferens were performed as described by Eltze (1988).

Male New Zealand white rabbits were killed by i.v. injection of pentobarbital sodium $(120 \mathrm{mg} / \mathrm{kg})$. Vasa deferentia were removed and segments of 1.5 cm length were suspended in $7 \mathrm{ml}$ organ baths containing modified Krebs buffer (composition in $\mathrm{mM}: \mathrm{NaCl} 118.0, \mathrm{KCl}$ 4.7, $\mathrm{CaCl}_{2} 2.5, \mathrm{MgSO}_{4}$ 0.6, $\mathrm{KH}_{2} \mathrm{PO}_{4}$ 1.2, $\mathrm{NaHCO}_{3}$ 25.0, (+)-glucose 11.1; $10^{-6} \mathrm{M}$ yohimbine was included to block $\alpha_{2}$ adrenoceptors) gassed with $95 \% \mathrm{O}_{2}-5 \% \mathrm{CO}_{2}$ at $31^{\circ} \mathrm{C}$. A resting tension of $0.75 \mathrm{~g}$ was applied and isometric twitch contractions were elicited by electrical field stimulation $(0.05 \mathrm{~Hz}, 0.5 \mathrm{~ms}, 30 \mathrm{~V})$. These effects were concentration dependently inhibited by the $\mathbf{M}_{1}$-selective agonist, 4-(4-chlorophenylcarbamoyloxy)-2-butynyltrimethylammonium iodide (4-Cl-McN-A-343) (Eltze et al., 1988) and recorded as with the atria.

\subsection{Isolated atria and ileum of the guinea-pig and rat}

Adult guinea-pigs and Wistar rats of either sex were killed by a blow to the head. Left atria and ileum were set up under $0.5 \mathrm{~g}$ tension in $6 \mathrm{ml}$ organ baths containing oxygenated $\left(95 \% \mathrm{O}_{2}-5 \%\right.$ $\mathrm{CO}_{2}$ ) Tyrode solution $\left(32^{\circ} \mathrm{C}\right.$; composition in $\mathrm{mM}$ : $\mathrm{NaCl} 137.0, \mathrm{KCl} 2.7, \mathrm{CaCl}_{2} 1.8, \mathrm{MgCl}_{2}$ 1.05, $\mathrm{NaHCO}_{3}$ 11.9, $\mathrm{NaH}_{2} \mathrm{PO}_{4}$ 0.42, (+)-glucose 5.6).

The atria were paced at $2 \mathrm{~Hz}$, with bipolar platinum electrodes, square-wave pulses of threshold $(+50 \%)$ voltage and $3 \mathrm{~ms}$ pulse width. Negative inotropic responses to the cumulative addition of the muscarinic agonist, arecaidine propargyl ester (Mutschler and Hultzsch, 1973; Moser et al., 1989) were measured as changes in isometric ten- sion. A force-displacement transducer connected to a Hellige amplifier and a multichannel recorder were used for these measurements. Strips of ileal longitudinal muscle $(1.5 \mathrm{~cm}$ length) were prepared according to Paton and Zar (1968). The tissue responses to the cumulative addition of arecaidine propargyl ester were measured as isotonic contractions and recorded as with the atria.

\subsection{Isolated superior cervical ganglion of the rat}

Experiments on ganglia were performed as described by Brown et al. (1980). Superior cervical ganglia were excised from male Sprague-Dawley rats $(200-300 \mathrm{~g})$ that had been anaesthetized with urethane $(1.2 \mathrm{~g} / \mathrm{kg}$ i.p.). Each ganglion was desheathed, suspended vertically in a separate heated chamber $\left(36^{\circ} \mathrm{C}\right)$ and superfused with oxygenated $\left(\begin{array}{lll}95 \% & \mathrm{O}_{2}-5 \% & \mathrm{CO}_{2}\end{array}\right) \mathrm{Krebs}$ solution $(1 \mathrm{ml} / \mathrm{min})$ which consisted of $(\mathrm{mM}): \mathrm{NaCl} 124.0, \mathrm{KCl} 3.0$, $\mathrm{NaHCO}_{3} 26.0, \mathrm{NaH}_{2} \mathrm{PO}_{4} 1.25, \mathrm{CaCl}_{2} 2.0, \mathrm{MgCl}_{2}$ 2.0 and (+)-glucose 10.0. The muscarine-induced depolarization $\left(\mathrm{EC}_{50}=40 \mathrm{nM}\right)$ was recorded differentially, via two calomel electrodes, between the ganglion and its postganglionic trunk. The DC potentials were amplified by microvoltmeters (Keithley 177) and were monitored on a chart recorder. Concentration-response curves were made with single doses of muscarine applied at 20-45 min intervals, followed by a washout phase until the baseline was reached.

\subsection{Antagonist affinities}

The tissues were allowed to equilibrate for $30-60$ $\mathrm{min}$. Concentration-response curves to the agonists were obtained before and after adding an antagonist. $\mathrm{EC}_{50}$ values were determined for the control and the antagonist-shifted concentration-response curves. Unless indicated otherwise (table 1), at least three concentrations (log interval $=0.48$ ) of antagonists were tested in the three tissues, allowing 15-60 min equilibration time. Each concentration of antagonist was tested 3-5 times and the ratios of agonist molar $\mathrm{EC}_{50}$ values obtained in the absence and presence of antagonists were calculated. Schild plots were made, using linear regression, by the method of least squares. The slopes of 
these plots were not significantly $(\mathrm{P}>0.05)$ different from unity. The $\mathrm{pA}_{2}$ values were thus estimated by fitting the best straight line with a slope equal to unity (Tallarida et al., 1979).

\subsection{Antagonist combination experiments}

The effects of p-fluoro-hexahydro-sila-difenidol (7b) in combination with pirenzepine in rabbit vas deferens or hexahydro-sila-difenidol (1) in guineapig atria and ileum were investigated on the basis of dose ratio analysis (Paton and Rang, 1965). The concentration-response curves to the agonists in these experiments were made under control conditions then in the presence of pirenzepine (50 nM), hexahydro-sila-difenidol (atria: $3 \mu \mathrm{M}$; ileum: 100 $\mathrm{nM}$ ) or p-fluoro-hexahydro-sila-difenidol (vas deferens: $1 \mu \mathrm{M}$; atria: $3 \mu \mathrm{M}$; ileum: $100 \mathrm{nM}$ ) alone or with the respective two antagonists combined. The contact time for antagonists was always 30 min and the agonists used were 4-Cl-McN-A-343 (vas deferens) and arecaidine propargyl ester (atria and ileum), respectively. The experimental data for individual antagonist applications were used to calculate dose ratios (DR) expected for the combination for two models: expected single-site $=D_{1}$ $+\mathrm{DR}_{2}-1$ and expected independent sites $=\mathrm{DR}_{1}$ $\times \mathrm{DR}_{2}$. These dose ratios were compared with the experimentally observed combined mean dose ratios.

\subsection{Statistics}

The data are presented as means \pm S.E.M. of 8-18 experiments with each preparation. The differences between mean values were tested for statistical significance $(P<0.05)$ by means of Student's t-test.

\subsection{Drugs}

Carbachol (carbamylcholine chloride), d,lmuscarine chloride and yohimbine hydrochloride (Sigma); oxotremorine sesquifumarate (Ega-Chemie); pirenzepine dihydrochloride (Boehringer Ingelheim); methoctramine tetrahydrochloride (kindly provided by Dr C. Melchiorre, University of Bologna, Italy); McN-A-343 (4-(3-chlorophenylcarbamoyloxy)-2-butynyltrimethylammonium chloride) (Serva); arecaidine propargyl ester (Mutschler and Hultzsch, 1973), 4-Cl-McN-A-343 (4-(4-chlorophenylcarbamoyloxy)-2-butynyltrimethylammonium iodide) (Nelson et al., 1976) as well as compounds $1-6,7 \mathrm{a}$ and $7 \mathrm{~b}$ were synthesized in our laboratories (Tacke et al, 1985: 1 ; silicon compounds $\underline{2}-\underline{6}$ and $7 \mathrm{~b}$ were prepared by analogy to the synthesis of the parent compound 1 and the carbon compound $7 \mathrm{a}$ was prepared by analogy to the synthesis of hexahydro-difenidol; unpublished results). The other chemicals were of reagent grade and were used as purchased.

Compounds $\underline{1}-\underline{6}, 7 \mathrm{a}$ and $7 \mathrm{~b}$ possess a centre of chirality and therefore exist in two enantiomers. They were used as racemates because indications were found that the enantiomers of silanols of this type may racemize in aqueous solution (Tacke et al., 1987).

\section{Results}

The inhibition of twitch contraction induced by 4-Cl-McN-A-343 ( $\left.\mathrm{EC}_{50}=250 \mathrm{nM}\right)$ in field-stimulated rabbit vas deferens and the muscarine-induced depolarization in rat ganglia as well as the arecaidine propargyl ester-mediated responses in atria and ileum of guinea-pigs and rats were antagonized by compounds $\underline{1}-\underline{6}, \underline{7 a}$ and $\underline{7 b}$. The antagonists produced concentration-dependent parallel shifts of the agonist concentration-response curves without either basal tension or maximum response being affected at the concentration range tested. The Schild plots were linear and the slopes were not significantly different from unity (P>0.05). Thus, all compounds were apparently simple competitive muscarinic antagonists. These results are summarized in tables 1 and 2 .

\subsection{Antagonist affinities in rabbit vas deferens and guinea-pig atria and ileum}

Compounds $\underline{1}-\underline{6}, 7 \mathrm{a}$ and $7 \mathrm{~b}$ showed quite wide variations in their affinities to the muscarinic receptors in vas deferens, atria and ileum, their $\mathrm{pA}_{2}$ values (table 1) differing by more than two orders of magnitude. As with the parent compound, hexahydro-sila-difenidol (1), the derivatives 2-6 and $7 \mathrm{a}$ exhibited similar affinities at receptors 
TABLE 1

Affinity profiles of pirenzepine, methoctramine and compounds $\underline{1}-\underline{6}, 7 \mathrm{a}$ and $7 \mathrm{~b}$ at muscarinic $\mathrm{M}_{1}$-receptors in rabbit vas deferens (RVD) and at $\mathrm{M}_{2}$-receptors in guinea-pig atria (GPA) as well as at $\mathrm{M}_{3}$-receptors in guinea-pig ileum (GPI). $\mathrm{pA}_{2}$ values and slopes of Schild plots (in parentheses) were calculated as described in Methods (antagonist affinities) and are presented as means \pm S.E.M. The ratios of affinity constants are given as a measure of receptor selectivity. These values were calculated from the antilogs of the differences between respective $\mathrm{pA}_{2}$ values.

\begin{tabular}{|c|c|c|c|c|c|c|}
\hline & \multicolumn{3}{|l|}{$\mathrm{pA}_{2}$} & \multicolumn{3}{|c|}{ Selectivity ratios } \\
\hline & $\overline{R V D-M_{1}}$ & GPA-M 2 & $\mathrm{GPI} \mathrm{M}_{3}$ & $\mathrm{M}_{1} / \mathrm{M}_{2}$ & $\mathrm{M}_{3} / \mathrm{M}_{1}$ & $\mathrm{M}_{3} / \mathrm{M}_{2}$ \\
\hline Pirenzepine $^{a}$ & $\begin{array}{c}8.24 \pm 0.06 \\
(1.19 \pm 0.10)\end{array}$ & $\begin{array}{c}6.82 \pm 0.03 \\
(0.98 \pm 0.02)\end{array}$ & $\begin{array}{c}6.88 \pm 0.04 \\
(1.07 \pm 0.04)\end{array}$ & 26 & 0.04 & 1.2 \\
\hline Methoctramine & $\begin{array}{c}6.85 \pm 0.07^{\mathrm{a}} \\
(1.19 \pm 0.10)\end{array}$ & $\begin{array}{c}7.69 \pm 0.03 \\
(1.05 \pm 0.05)\end{array}$ & $\begin{array}{c}6.17 \pm 0.05 \\
(0.99 \pm 0.09)\end{array}$ & 0.15 & 0.21 & 0.03 \\
\hline$\underline{1}^{a, b}$ & $\begin{array}{c}7.92 \pm 0.07 \\
(1.09 \pm 0.03)\end{array}$ & $\begin{array}{c}6.53 \pm 0.05 \\
(0.96 \pm 0.09)\end{array}$ & $\begin{array}{c}7.96 \pm 0.03 \\
(0.93 \pm 0.06)\end{array}$ & 25 & 1.1 & 27 \\
\hline$\underline{2}$ & $\begin{array}{c}7.78 \pm 0.09^{\mathrm{d}} \\
(1.07 \pm 0.04)\end{array}$ & $\begin{array}{c}6.73 \pm 0.04 \\
(0.96 \pm 0.04)\end{array}$ & $\begin{array}{c}8.13 \pm 0.05 \\
(0.88 \pm 0.08)\end{array}$ & 11 & 2.2 & 25 \\
\hline$\underline{3}$ & $\begin{array}{c}7.13 \pm 0.10^{d} \\
(1.23 \pm 0.07)\end{array}$ & $5.92 \pm 0.04$ & $\begin{array}{c}7.48 \pm 0.02 \\
(1.06 \pm 0.05)\end{array}$ & 16 & 2.2 & 36 \\
\hline 4 & $\begin{array}{c}6.77 \pm 0.10^{d} \\
(1.21 \pm 0.06)\end{array}$ & $5.79 \pm 0.06^{c}$ & $\begin{array}{c}6.74 \pm 0.05 \\
(0.99 \pm 0.11)\end{array}$ & 9.5 & 0.93 & 8.9 \\
\hline$\underline{5}$ & $\begin{array}{c}6.74 \pm 0.08^{d} \\
(1.06 \pm 0.04)\end{array}$ & $5.59 \pm 0.03^{c}$ & $\begin{array}{c}7.09 \pm 0.06 \\
(0.94 \pm 0.12)\end{array}$ & 14 & 2.2 & 32 \\
\hline$\underline{6}$ & $\begin{array}{c}6.82 \pm 0.07 \\
(1.08 \pm 0.21)\end{array}$ & $5.50 \pm 0.05^{c}$ & $\begin{array}{c}7.06 \pm 0.03 \\
(0.93 \pm 0.07)\end{array}$ & 21 & 1.7 & 36 \\
\hline 7a & $\begin{array}{c}7.56 \pm 0.07 \\
(0.95 \pm 0.16)\end{array}$ & $\begin{array}{c}6.58 \pm 0.03 \\
(1.05 \pm 0.08)\end{array}$ & $\begin{array}{c}7.93 \pm 0.03 \\
(0.89 \pm 0.04)\end{array}$ & 9.5 & 2.3 & 22 \\
\hline$\underline{7 b}^{a}$ & $\begin{array}{c}6.68 \pm 0.03^{\mathrm{e}} \\
(1.12 \pm 0.21)\end{array}$ & $6.01 \pm 0.06^{c}$ & $\begin{array}{r}7.84 \pm 0.03 ' \\
(1.08 \pm 0.06)\end{array}$ & 4.7 & 15 & 68 \\
\hline
\end{tabular}

a Data taken from Eltze and Figala (1988) and Lambrecht et al. (1988a). ${ }^{\text {b }}$ Hexahydro-sila-difenidol. " Only one or two concentrations of the antagonists were investigated due to the negative inotropic effects of the antagonists themselves at higher concentrations: $\underline{3}(1 \mu \mathrm{M}), \underline{4}(3 \mu \mathrm{M}), \underline{5}(3$ and $10 \mu \mathrm{M}), \underline{6}(1 \mu \mathrm{M}), 7 \mathrm{~b}(1$ and $3 \mu \mathrm{M})$. The $\mathrm{pA}_{2}$ values were therefore determined from the individual dose ratios according to Tallarida et al. (1979). ${ }^{\mathrm{d}} \mathrm{pA}_{2}$ values and slopes of Schild plots taken from Eltze et al. (1988). ${ }^{\mathrm{C}} \mathrm{A} \mathrm{pA}_{2}$ value of $6.95 \pm 0.04$ was obtained using $\mathrm{McN}-\mathrm{A}-343$ as agonist. ' $\mathrm{pA}_{2}$ values of $7.83 \pm 0.08$ and $7.89 \pm 0.07$ were obtained using carbachol and oxotremorine, respectively, as agonists.

TABLE 2

The affinities of hexahydro-sila-difenidol (1) and p-fluoro-hexahydro-sila-difenidol (7b) for muscarinic $\mathrm{M}_{1}$-receptors in rat superior cervical ganglia (RG), $M_{2}$-receptors in rat atria (RA) and $M_{3}$-receptors in rat ileum (RI). $p A_{2}$ values and slopes of Schild plots (in parentheses) are presented as means \pm S.E.M. The ratios of affinity constants are given as a measure of receptor selectivity. These values were calculated from the antilogs of the differences between respective $\mathrm{pA}_{2}$ values.

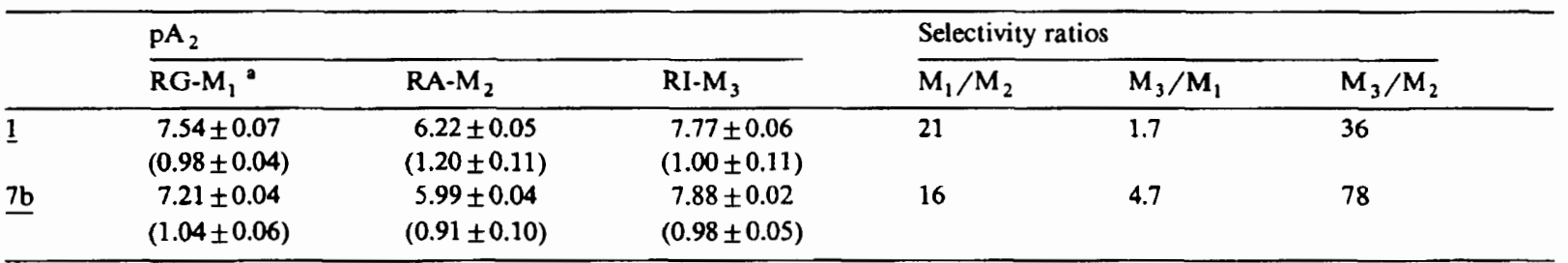

\footnotetext{
- The $\mathrm{pA}_{2}$ value observed in this preparation for pirenzepine was 8.30 (Lambrecht et al., 1988c).
} 

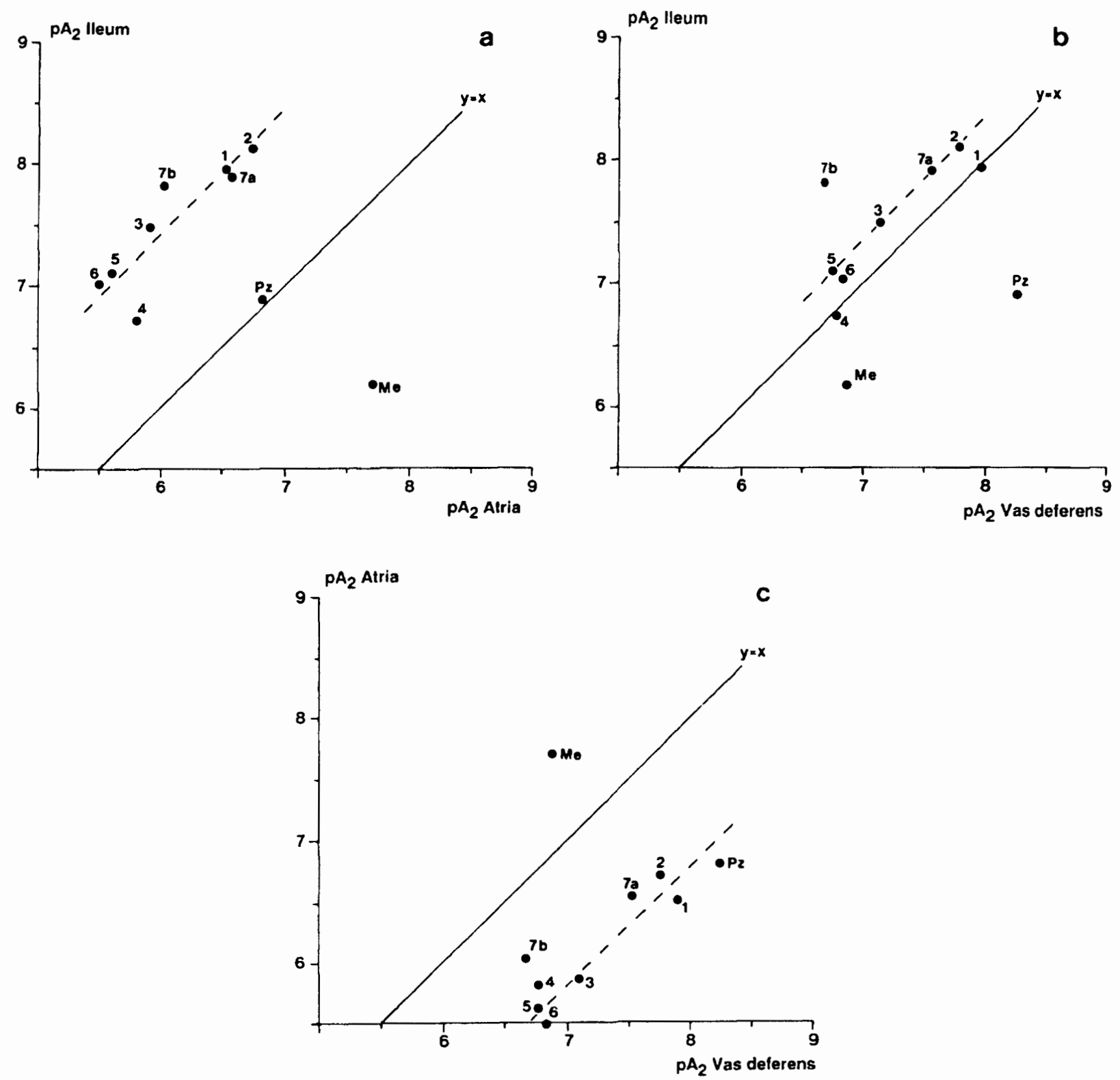

Fig. 3. Comparison of the affinities $\left(\mathrm{pA}_{2} ;\right.$ table 1$)$ of pirenzepine $(\mathrm{Pz})$, methoctramine $(\mathrm{Me})$ and compounds $\underline{1}-\underline{6}, 7 \mathrm{a}$ and $7 \mathrm{~b}$ at muscarinic $M_{1}$-receptors in rabbit vas deferens (panels b and c), $M_{2}$-receptors in guinea-pig atria (panels a and c) and $\bar{M}_{3}$-receptors in guinea-pig ileum (panels a and b). If the affinities are not the same for two receptors, the results deviate from the theoretical equality line $(y=x)$, and the distance from this line is then a measure of receptor selectivity. The dotted lines represent the following receptor selectivity ratios, panel a: $M_{3}$ (ileum) $/ M_{2}$ (atria) $=25 ;$ panel b: $M_{3}$ (ileum) $/ M_{1}$ (vas deferens) $=2.2 ;$ panel c: $M_{1}$ (vas deferens) $/ M_{2}$ (atria) $=15$.

present in the vas deferens and ileum (dotted line in fig. 3 , panel $b$ ), but the $\mathrm{pA}_{2}$ values obtained in atria were much lower. This selectivity profile of the compounds is demonstrated by the selectivity ratios given in table 1 and is illustrated in fig. 3 .
A different selectivity pattern was observed for p-fluoro-hexahydro-sila-difenidol (7b). This antimuscarinic agent exhibited the highest affinity $\left(\mathrm{pA}_{2}=7.84\right)$ for the receptors in the ileum, an intermediate affinity for the receptors in vas de- 
ferens $\left(\mathrm{pA}_{2}=6.68\right)$ and lowest affinity for the cardiac receptors $\left(\mathrm{pA}_{2}=6.01\right)$.

\subsection{Antagonist affinities in rat ganglia, atria and ileum}

Hexahydro-sila-difenidol (1) and its p-fluoro derivative $7 \mathrm{~b}$ were tested in three isolated preparations of the rat: superior cervical ganglia $\left(\mathrm{M}_{1}\right)$, atria $\left(\mathrm{M}_{2}\right)$ and ileal longitudinal muscle $\left(\mathrm{M}_{3}\right)$. The $\mathrm{pA}_{2}$ values and corresponding Schild slopes are shown in table 2. Although there were some quantitative differences, both compounds showed qualitatively the same receptor selectivity profile as was found in rabbit vas deferens and guinea-pig atria and ileum (table 1); hexahydro-sila-difenidol: $M_{1} \approx M_{3}>M_{2}$, p-fluoro-hexahydro-sila-difenidol: $M_{3}>M_{1}>M_{2}$.

\subsection{Combination experiments}

The mutual competition between p-fluorohexahydro-sila-difenidol (7b) and pirenzepine or

\section{TABLE 3}

Summary of dose ratio analysis from the p-fluoro-hexahydrosila-difenidol (7b) combination experiments. Each dose ratio (DR) is the mean \pm S.E.M. and the number of observations is given in parentheses.

\begin{tabular}{|c|c|}
\hline & Mean dose ratio \\
\hline \multicolumn{2}{|l|}{ Rabbit vas deferens $\left(M_{1}\right)$} \\
\hline Pirenzepine (50 nM) & $6.8 \pm 0.8(n=5)$ \\
\hline Compound $7 \mathrm{~b}(1 \mu \mathrm{M})$ & $15 \pm 2.3(n=5)$ \\
\hline Expected single site $\mathrm{DR}^{\mathrm{a}}$ & 20.8 \\
\hline Experimental combination DR & $27 \pm 2.5(n=5)$ \\
\hline Expected independent site $\mathrm{DR}^{\mathrm{b}}$ & 102 \\
\hline \multicolumn{2}{|l|}{ Guinea-pig atria $\left(M_{2}\right)$} \\
\hline Compound $\underline{1}^{\mathrm{c}}(3 \mu \mathrm{M})$ & $12 \pm 1.2(n=6)$ \\
\hline Compound $\overline{7 b}(3 \mu \mathrm{M})$ & $3.9 \pm 0.1(n=6)$ \\
\hline Expected single site DR & 14.9 \\
\hline Experimental combination DR & $18 \pm 4.5(n=6)$ \\
\hline Expected independent site $D R^{b}$ & 47 \\
\hline \multicolumn{2}{|l|}{ Guinea-pig ileum $\left(M_{3}\right)$} \\
\hline Compound $\underline{1}^{\mathrm{c}}(100 \mathrm{nM})$ & $16 \pm 2.2(n=8)$ \\
\hline Compound $\overline{7 b}(100 \mathrm{nM})$ & $8.7 \pm 0.8(n=8)$ \\
\hline Expected single site DR & 23.7 \\
\hline Experimental combination DR & $20 \pm 2.7(n=8)$ \\
\hline Expected independent site $\mathrm{DR}^{\mathrm{b}}$ & 139 \\
\hline
\end{tabular}

a $\mathrm{DR}_{1}+\mathrm{DR}_{2}-1 .^{\mathrm{b}} \mathrm{DR} \mathrm{R}_{1} \times \mathrm{DR}_{2}{ }^{\mathrm{c}}$ Hexahydro-sila-difenidol. the parent compound 1 was investigated in rabbit vas deferens and guinea-pig atria and ileum, respectively, on the basis of dose ratio analysis (Paton and Rang, 1965). The results of these experiments are summarized in table 3 . The combined dose ratios obtained experimentally in the three preparations were very close to those calculated for two antagonists acting at a single site. The results are not consistent $(\mathrm{P}<0.05)$ with a multiplication of dose ratios which would be expected if two antagonists interacted at independent sites.

\section{Discussion}

\subsection{General considerations}

The presynaptic muscarinic receptors in rabbit vas deferens and the postsynaptic receptors in guinea-pig atria and ileum have been well established to belong to different subclasses: ganglionic $\mathbf{M}_{1^{-}}$, cardiac $\mathbf{M}_{2^{-}}$and smooth muscle/glandular $M_{3}$-receptors (Eltze, 1988; Eltze and Figala, 1988; Eltze et al., 1988; Lambrecht et al., 1988a-c; 1989). This heterogeneity is based mainly on the different affinities of selective antagonists such as pirenzepine $\left(M_{1}>M_{2} \approx M_{3}\right)$, methoctramine $\left(M_{2}\right.$ $\left.>M_{1}>M_{3}\right)$ and hexahydro-sila-difenidol (1; $M_{1}$ $\approx M_{3}>M_{2}$ ) (table 1).

The present study concerned the effects of changing the size of the cyclic amino group (compounds $\underline{2}$ and $\underline{3}$ ) and introducing substituents in the phenyl ring (compounds $\underline{4}-\underline{6}, 7 \mathrm{~b}$ ) of hexahydro-sila-difenidol (1) as well as of replacing the central silicon atom of compound $7 \mathrm{~b}$ by a carbon atom (compound $7 \mathrm{a}$ ) on muscarinic potency.

The principal conclusions drawn from these experiments are that: (1) compounds $\underline{1}-\underline{6}, 7 \mathrm{a}$ and $7 \mathrm{~b}$ act as competitive muscarinic antagonists in rabbit vas deferens as well as in guinea-pig atria and ileum. They produced an antagonism that was reversible and surmountable and their apparent affinity in each tissue appeared to be independent of the concentrations used. Thus, Schild analysis yielded slopes which were not significantly different from unity (table 1). The affinity constants of p-fluoro-hexahydro-sila-difenidol $(\underline{7 b})$ in rabbit 
vas deferens and guinea-pig ileum were independent of the agonist used (rabbit vas deferens: $\mathrm{McN}-\mathrm{A}-343=6.95 ; \quad 4-\mathrm{Cl}-\mathrm{McN}-\mathrm{A}-343=6.68$; guinea-pig ileum: arecaidine propargyl ester $=$ 7.84 ; carbachol $=7.83$; oxotremorine $=7.89$ ) (table 1). In addition to the data obtained from the Schild analysis, combination studies (table 3) showed compound $7 \mathrm{~b}$ to act in a manner indistinguishable from 'classical' competitive antagonists. (2) Structural variations in the hexahydrosila-difenidol molecule led to new muscarinic antagonists which exhibit a qualitatively and/or quantitatively different spectrum of receptor selectivity to the parent compound. The selectivity observed does not appear to be associated with high affinity as there are less potent compounds with appreciable selectivity (compounds $\underline{4}-\underline{6}$; table 1 and fig. 3).

\subsection{Structure-selectivity relationships}

The influence of the ring size of the cyclic amino group on potency and selectivity can be demonstrated by comparison of compounds $\underline{1}-\underline{3}$. As can be seen from the data in table 1 the affinity to the three muscarinic receptor subtypes depends on the nature of the heterocyclic ring system and varies up to about 6 -fold. Compound 2, containing a pyrrolidino ring, shows nearly the same affinity to $\mathrm{M}_{1^{-}}, \mathrm{M}_{2^{-}}$and $\mathrm{M}_{3}$-receptors as the parent compound, hexahydro-sila-difenidol (1). In contrast, ring extension to the hexamethyleneimino derivative 3 results in a decrease in affinity for all subtypes. However, the influence of the size of the cyclic amino group on selectivity is moderate as compounds $\underline{2}$ and $\underline{3}$ showed the same selectivity pattern as the parent compound $1: M_{1} \approx M_{3}>M_{2}$. Therefore compounds 1- $\underline{3}$ deviate significantly from the line of equivalence when the $\mathrm{pA}_{2}$ values in guinea-pig atria are compared to those in the ileum and rabbit vas deferens, respectively (fig. 3 , panels a and c).

Comparison of compounds $1,4-6$ and $7 \mathrm{~b}$ defines the effect of substituents in the phenyl ring of hexahydro-sila-difenidol. Either a methoxy substituent in the ortho or para position (compounds 4 and 5) or a para-chloro substituent (compound 6) reduces the affinity to the muscarinic receptors up to more than one order of magnitude (table 1). Thus, compounds $\underline{4}-\underline{6}$ were even less potent than the hexamethyleneimino derivative 3 . On the other hand, compounds $4-6$ retain the same selectivity profile as the parent compound $\underline{1}$ and the derivatives 2 and $\underline{3}: \mathrm{M}_{1} \approx \mathrm{M}_{3}>\mathrm{M}_{2}$ (table 1 and fig. 3 ). A novel affinity profile was observed for $\mathrm{p}$ fluoro-hexahydro-sila-difenidol (7b): $\mathbf{M}_{3}>\mathrm{M}_{1}>$ $\mathbf{M}_{2}$. This compound exhibited high affinity for smooth muscle $\mathrm{M}_{3}$-receptors in guinea-pig ileum $\left(\mathrm{pA}_{2}=7.84\right)$ while its antimuscarinic potency at $\mathbf{M}_{1}$-receptors in rabbit vas deferens and cardiac $\mathbf{M}_{2}$-receptors in guinea-pig atria was lower by factors of 15 and 68 , respectively (table 1 , fig. 3 ). This novel selectivity profile of $7 \mathrm{~b}$ is based on the fact that the para-fluoro substituent leads to a decrease in $\mathbf{M}_{1}$ - and $\mathbf{M}_{2}$-antimuscarinic potency while only slightly affecting the affinity towards $M_{3}$-receptors.

The $\mathrm{pA}_{2}$ values determined for $\mathrm{p}$-fluoro-hexahydro-sila-difenidol (7b) in rat atria and ileum (5.99 and 7.88, respectively; table 2 ) were very close to that found in the corresponding guinea-pig tissues (6.01 and 7.84, respectively; table 1 ). The $\mathrm{pA}_{2}$ value observed for compound $7 \mathrm{~b}$ at $\mathrm{M}_{1}$-receptors in rat superior cervical ganglia (7.21 using muscarine as agonist; table 3) was slightly higher than that found in rabbit vas deferens (6.68 using 4-Cl-McN-A-343 and 6.95 using McN-A-343 as agonists; table 1). However, the data obtained with the three rat tissues show that the receptor selectivity profile of $p$-fluoro-hexahydro-sila-difenidol $\left(\mathbf{M}_{3}>\mathbf{M}_{1}>\mathbf{M}_{2}\right)$ is species-independent. This also holds for the parent compound, hexahydrosila-difenidol $\left(M_{1} \approx M_{3}>M_{2}\right.$; tables 1 and 2).

Replacement of the central silicon atom in compound $7 \mathrm{~b}$ by a carbon atom $(7 \mathrm{~b} \rightarrow 7 \mathrm{a})$ increased the affinity for $\mathrm{M}_{1}$-receptors in rabbit vas deferens as well as for cardiac $\mathbf{M}_{2}$-receptors in guinea-pig atria by factors of 8 and 4 , respectively, whereas the affinity to $M_{3}$-receptors in guinea-pig ileum was not changed significantly $(P>0.05)$ (table 1). Thus, the selectivity profile of p-fluorohexahydro-difenidol (7a) is similar to that of the silicon compounds $1-\overline{6}$ (fig. 3 ), but differs from that of its sila analogue $7 \mathrm{~b}$ ). This is a further example indicating that sila substitution $(\mathrm{C} / \mathrm{Si}$ exchange) may be a useful tool to improve recep- 
tor selectivity (for a recent review on C/Si-bioisosterism, see Tacke and Linoh, 1989).

In conclusion this report describes structure-activity relationships of antimuscarinics related to hexahydro-sila-difenidol (). $)$. The antimuscarinic potency and selectivity in this series of compounds (1-6, 7a and $7 \mathrm{~b}$; fig. 2 ) is controlled by the substitution pattern of the phenyl moiety, the structure of the cyclic amino group and the nature of the central atom 'El' (carbon or silicon). Compounds with qualitatively and/or quantitatively different receptor selectivity profiles were obtained. Among the antimuscarinic agents tested in this study, p-fluoro-hexahydro-sila-difenidol (7b) is the only compound which showed appreciable $M_{3}$-receptor selectivity $\left(M_{3}>M_{1}>M_{2}\right)$. Its affinity profile is different from that of the parent compound, hexahydro-sila-difenidol (1) $\left(M_{1} \approx M_{3}\right.$ $>M_{2}$ ), and its selectivity for $\mathbf{M}_{3}$-receptors is comparable to that of pirenzepine for $\mathrm{M}_{1}$ - and methoctramine for $\mathbf{M}_{2}$-receptors (fig. 3). $\mathrm{p}$ Fluoro-hexahydro-sila-difenidol (7b) therefore represents a useful tool for the subclassification of muscarinic receptors.

\section{Acknowledgements}

The authors gratefully acknowledge the skillful technical assistance of Mrs. C. Gillessen. G.L. and E.M. thank the Fonds der Chemischen Industrie and Ratiopharm for financial support. R.T. thanks the Deutsche Forschungsgemeinschaft and the Fonds der Chemischen Industrie for financial support as well as Bayer AG for providing chemicals. We would also like to thank Dr. Lay Khoon Choo for helpful suggestions.

\section{References}

Akiba, I., T. Kubo, A. Maeda, H. Bujo, J. Nakai, M. Mishina and S. Numa, 1988, Primary structure of porcine muscarinic acetylcholine receptor III and antagonist binding studies, FEBS Lett. 235, 257.

Birdsall, N.J.M. and E.C. Hulme, 1983, Muscarinic receptor subclasses, Trends Pharmacol. Sci. 4, 459.

Brann, M.R., N.J. Buckley and T.I. Bonner, 1988, The striatum and cerebral cortex express different muscarinic receptor mRNAs, FEBS Lett. 230, 90.

Brown, D.A., S. Fatherazi, J. Garthwaite and R.D. White, 1980, Muscarinic receptors in rat sympathetic ganglia, Br. J. Pharmacol. 70, 577.
Buckley, N.J., T.I. Bonner, C.M. Buckley and M.R. Brann, 1989. Antagonist binding properties of five cloned muscarinic receptors expressed in CHO-K1 cells, Mol. Pharmacol. 35, 469.

Doods, H.N., M.I. Mathy, D. Davidesko, K.J. Van Charldorp, A. De Jonge and P.A. Van Zwieten, 1987, Selectivity of muscarinic antagonists in radioligand and in vivo experiments for the putative $M_{1}, M_{2}$ and $M_{3}$ receptors, $J$. Pharmacol. Exp. Ther. 242, 257.

Eglen, R.M. and R.L. Whiting, 1986, Muscarinic receptor subtypes: A critique of the current classification and a proposal for a working nomenclature, J. Auton. Pharmacol. $5,323$.

Eltze, $M ., 1988$, Muscarinic $M_{1}$ - and $M_{2}$-receptors mediating opposite effects on neuromuscular transmission in rabbit vas deferens, European J. Pharmacol. 151, 205.

Eltze, M. and V. Figala, 1988, Affinity and selectivity of biperiden enantiomers for muscarinic receptor subtypes. European J. Pharmacol. 158, 11.

Eltze, M., G. Gmelin, J. Wess, C. Strohmann, R. Tacke, E. Mutschler and G. Lambrecht, 1988, Presynaptic muscarinic receptors mediating inhibition of neurogenic contractions in rabbit vas deferens are of the ganglionic $M_{1}$-type, European J. Pharmacol. 158, 233.

Fuder, H., H. Kilbinger and H. Müller, 1985, Organ selectivity of hexahydrosiladifenidol in blocking pre- and postjunctional muscarinic receptors studied in guinea-pig ileum and rat heart, European J. Pharmacol. 113, 125.

Giraldo, E., M.A. Vigano, R. Hammer and H. Ladinsky, 1988, Characterization of muscarinic receptors in guinea-pig ileum longitudinal smooth muscle, Mol. Pharmacol. 33, 617.

Hammer, R., C.P. Berrie, N.J.M. Birdsall, A.S.V. Burgen and E.C. Hulme, 1980, Pirenzepine distinguishes between different subclasses of muscarinic receptors, Nature 283, 90.

Hammer, R. and A. Giachetti, 1982, Muscarinic receptor subtypes: $M_{1}$ and $M_{2}$, biochemical and functional characterization, Life Sci. 31, 2991.

Kerlavage, A.R., C.M. Fraser and J.C. Venter, 1987, Muscarinic cholinergic receptor structure: molecular biological support for subtypes, Trends Pharmacol. Sci. 8, 426.

Lambrecht, G., R. Feifel, B. Forth, C. Strohmann, R. Tacke and E. Mutschler, 1988a, p-Fluoro-hexahydro-sila-difenidol: The first $\mathrm{M}_{2 \beta}$-selective muscarinic antagonist, European J. Pharmacol. 152, 193.

Lambrecht, G., R. Feifel, U. Moser, A.J. Aasen, M. Waelbroeck, J. Christophe and E. Mutschler, 1988b, Stereoselectivity of the enantiomers of trihexyphenidyl and its methiodide at muscarinic receptor subtypes, European J. Pharmacol. 155. 167.

Lambrecht, G., G. Gmelin, K. Rafeiner, C. Strohmann, R. Tacke and E. Mutschler, 1988c, o-Methoxy-sila-hexocyclium: a new quaternary $\mathbf{M}_{1}$-selective muscarinic antagonist, European J. Pharmacol. 151, 155.

Lambrecht, G., J. Wess, R. Tacke and E. Mutschler, 1989, Heterogeneity of muscarinic receptors: Evidence from structure-activity relationships of antimuscarinic agents related to pridinol and sila-pridinol, in: Trends in Medicinal 
Chemistry 88, eds. H. Van der Goot, G. Domány, L. Pallos and H. Timmerman (Elsevier Science Publishers B.V., Amsterdam) p. 265.

Melchiorre, C., 1988, Polymethylene tetraamines: A new generation of selective muscarinic antagonists, Trends Pharmacol. Sci. 9, 216

Melchiorre, C., P. Angeli, G. Lambrecht, E. Mutschler, M.T. Picchio and J. Wess, 1987, Antimuscarinic action of methoctramine, a new cardioselective $\mathbf{M} \cdot \mathbf{2}$ muscarinic receptor antagonist, alone and in combination with atropine and gallamine, European J. Pharmacol. 144, 117.

Micheletti, R., E. Montagna and A. Giachetti, 1987, AF-DX 116, a cardioselective muscarinic antagonist, J. Pharmacol. Exp. Ther. 241, 628.

Mitchelson, F., 1988, Muscarinic receptor differentiation, Pharmacol. Ther. 37, 357.

Moser, U., G. Lambrecht, M. Wagner, J. Wess and E. Mutschler, 1989, Structure-activity relationships of new analogues of arecaidine propargyl ester at muscarinic M1 and $\mathrm{M} 2$ receptor subtypes, Br. J. Pharmacol. 96, 319.

Mutschler, E. and K. Hultzsch, 1973, Über StrukturWirkungs-Beziehungen von ungesättigten Estern des Arecaidins und Dihydroarecaidins, Arzneim. Forsch. 23, 732.

Mutschler, E., U. Moser, J. Wess and G. Lambrecht, 1988, New approaches to the subclassification of muscarinic receptors, in: Recent Advances in Receptor Chemistry, eds. C. Melchiorre and M. Giannella (Elsevier Science Publishers B.V., Amsterdam) p. 195.

Nelson, W.L., D.S. Freeman and F.F. Vincenzi, 1976, Stereochemical analogs of a muscarinic ganglionic stimulant. 2 . Cis and trans olefinic, epoxide, and cyclopropane analogs related to McN-A-343, J. Med. Chem. 19, 153.

Paton, W.D.M. and H.P. Rang, 1965, The uptake of atropine and related drugs by intestinal smooth muscle of the guinea pig in relation to acetylcholine receptors, Proc. R. Soc. London Ser. B 163, 1.

Paton, W.D.M. and M.A. Zar, 1968, The origine of acetylcholine released from guinea-pig intestine and longitudinal muscle strips, J. Physiol. 194, 13.

Peralta, E.G., A. Ashkenazi, J.W. Winslow, D.H. Smith, J. Ramachandran and D.J. Capon, 1987, Distinct primary structures, ligand-binding properties and tissue-specific expression of four human muscarinic acetylcholine receptors, EMBO J. 6, 3923.

Tacke, R. and B. Becker, 1987, Sila-substitution of drugs and biotransformation of organosilicon compounds, Main Group Met. Chem. 10, 169.

Tacke, R. and H. Linoh, 1989, Bioorganosilicon Chemistry, in: The Chemistry of Organic Silicon Compounds, Part 2, eds. S. Patai and Z. Rappoport (John Wiley \& Sons Ltd., Chichester) p. 1143.

Tacke, R., H. Linoh, L. Ernst, U. Moser, E. Mutschler, S. Sarge, H.K. Cammenga and G. Lambrecht, 1987, Preparation and properties of the enantiomers of the antimuscarinic agents sila-procyclidine and sila-tricyclamol iodide: Optically active silanols with silicon as the centre of chirality, Chem. Ber. 120, 1229.

Tacke, R., H. Linoh, D. Schomburg, L. Ernst, U. Moser, E. Mutschler and G. Lambrecht, 1986, On the absolute configuration of the enantiomers of the antimuscarinic agents procyclidine and tricyclamol iodide: $X$-ray structural analysis of (R)-1-(3-cyclohexyl-3-hydroxy-3-phenylpropyl)-1methylpyrrolidinium iodide, Liebigs Ann. Chem. 242.

Tacke, R., H. Linoh, H. Zilch, J. Wess, U. Moser, E. Mutschler and G. Lambrecht, 1985, Synthesis and properties of the selective antimuscarinic agent cyclohexylphenyl(3-piperidinopropyl)silanol, Liebigs Ann. Chem. 2223.

Tacke, R., C. Strohmann, S. Sarge, H.K. Cammenga, D. Schomburg, E. Mutschler and G. Lambrecht, 1989, Preparation and properties of the enantiomers of the selective antimuscarinic agent 1-cyclohexyl-1-phenyl-4-piperidinobutan-1-ol (Hexahydro-difenidol), Liebigs Ann. Chem. 137.

Tallarida, R.J., A. Cowan and M.W. Adler, 1979, $\mathrm{pA}_{2}$ and receptor differentiation: A statistical analysis of competitive antagonism, Life Sci. 25, 637.

Waelbroeck, M., J. Camus, M. Tastenoy and J. Christophe, $1988,80 \%$ of muscarinic receptors expressed by the NB-OK 1 human neuroblastoma cell line show high affinity for pirenzepine and are comparable to rat hippocampus M1 receptors, FEBS Lett. 226, 287.

Waelbroeck, M., M. Gillard, P. Robberecht and J. Christophe, 1986, Kinetic studies of $\left({ }^{3} \mathrm{H}\right)-\mathrm{N}$-methylscopolamine binding to muscarinic receptors in the rat central nervous system: evidence for the existence of three classes of binding sites, Mol. Pharmacol. 30, 305. 